\title{
HOW CAPITAL STRUCTURE AFFECTS BUSINESS VALUATION: A CASE STUDY OF SLOVAKIA
}

\author{
Valaskova, K., Lazaroiu, G., Olah, J., Siekelova, A., Lancova, B.
}

Katarina Valaskova, Anna Siekelova, Barbora Lancova / University of Zilina, Faculty of Operation and Economic of Transport and Communications, Department of Economics, Univerzitna 8215/1, 01026 Zilina, Slovakia.Email: katarina.valaskova@fpedas.uniza.sk, anna.siekelova@fpedas.uniza.sk.

George Lazaroiu / Spiru Haret University, Faculty of Social and Human Sciences, Department of SocialHuman Sciences, 041916 Bucharest, Romania.Email: phd_lazaroiu@yahoo.com.

Judit Olah / University of Debrecen, Institute of Applied Informatics and Logistics, Faculty of Economics and Business, 4032 Debrecen, Hungary. Email: olah.judit@econ.unideb.hu.

\begin{abstract}
A company's capital structure is a significant factor in valuing its business. The relative levels of equity and debt affect risk and cash flow and, therefore, the amount an investor would be willing to pay for the company or an interest in it. Capital structure matters because it influences the cost of capital. Therefore, this paper aims to quantify the effect of the capital structure on the cost of capital of Slovak enterprises and to suggest an effective way of financial decision-making. The data used in the study was gained from the Bratislava Stock Exchange because publicly available information on enterprises issuing their shares on the stock exchange was needed to calculate the cost of capital. Due to the underdeveloped capital market of Slovakia, we chose 17 stock companies (except for commercial banks) operating on the Slovak market having all the data required. The financial data of companies were obtained from their financial statements spanning 2013 to 2017 . The impact of the capital structure on the cost of capital was investigated by the Pearson correlation coefficient, regression analysis and Mann-Whitney $U$-test. The study found that there is an indirect relationship between the capital structure, the cost of capital and the size of the company. We also conclude that the growing volume of debt may result in a decline in the corporate costs of capital. These findings concerning Slovak enterprises incline to the respected compromise theory.
\end{abstract}

Keywords: capital structure, cost of debt, cost of equity, cost of capital JEL Classification: D24, G32

\section{Introduction}

The capital structure of a company has been of interest to many researchers over a long period because of its importance in financial decision-making. The volume of debt or equity capital decisively determines the long-term survival of a company. It is generally clear that the overall objective of companies is to maximize the wealth of the owners and thereby 
increase the value of the business. On the other hand, an enterprise creates value when it generates a return higher than the cost of capital.

Capital costs are, therefore, one of the most important factors in determining the value of companies. The main representatives who first began to deal with the impact of the capital structure on the cost of capital of business were Modigliani \& Miller (1958). According to their theories, the cost of capital of enterprises is considered to be independent of their capital structure under the assumption of a perfect market which, however, exists only in theory. Later on, other theorists began to work on this issue and reached different conclusions. Some theories suggest that the capital structure indirectly affects the cost of capital (e.g. Myers \& Majluf, 1984), other findings suggest that there is a direct relationship between the variables (e.g. Frank \& Goyal, 2009), and another group of theorists argue that the capital structure does not affect the cost of capital of enterprises (e.g. Luigi \& Sorin, 2009). In many researches concerning the capital structure and costs of capital as separate areas of financial management, the impact of capital structure on the costs of capital remains unclear. Different opinions of different researchers create a knowledge gap in determining the impact of capital structure on the costs of capital of a company. It was found that the cost of capital is an important factor when determining the value of a company because it is created when it provides higher revenues compared to these costs. Therefore, the results of the empirical study try to find out whether and how the capital structure influences the costs of capital of companies operating in the Slovak market. Their results proved the trade-off theory to be more exact in Slovak conditions. Since then, no other studies have been realized and thus the identified research gap is to be solved in this presented study.

Thus, the main aim of this paper is to quantify the effect of the capital structure on the cost of capital of selected enterprises operating in the Slovak market. The purpose of the paper is to clarify the question of the impact of the capital structure on the business valuation considering the sample of enterprises issuing their stocks on the Bratislava Stock Exchange. The analysis is focused on three pillar variables - capital structure, cost of capital, and company size.

The paper is divided into four main parts. The literature review highlights the current state of research in the field of corporate capital structure and its relation to the costs of capital. Data and Methodology depicts a brief description of business entities entering the empirical analysis. This section also specifies the methodological steps of empirical research. The results section is focused on the description of all findings, revealing the relationship between the capital structure of Slovak enterprises and costs of capital, finally resulting in the suggestion of an effective way of financial decision-making. The discussion describes the results, assesses the mutual dependence of the capital structure and the costs of equity, and compares the results with other studies conducted in conditions of the Slovak business environment.

\section{Literature review}

Capital structure has long been an area of interest for many theoreticians. The emergence of the Modigliani \& Miller theory in 1958 has led to the rise of many controversies. Their study states that the costs of capital are independent of the degree of external resources to equity in the capital structure of enterprises (Modigliani \& Miller, 1958). Many studies have been conducted, both locally and internationally to see if the Modigliani \& Miller theory is true or 
false. The results of studies were various and led to several conclusions, which can be attributed to the various measures that scientists used to determine the relationship between capital structure and capital costs (Barclay \& Smith, 1995).

Gapenski (1987) found in his significant study, that there was a strong positive relationship between leverage and costs of debt and equity. The relationship between the debt to equity ratio and the costs of capital was estimated by a regression model using the accounting and market value of the leverage indicator. From 1996 to 1999, 90 enterprises were selected and leverage was measured using a debt-to-total-assets ratio in 20 cases (Korajczyk \& Levy, 2003). Based on the results of this research, it was concluded that there is a negative relationship between the indicator and the cost of capital that, contrary to the previous research, is not in line with the capital structure theory of Modigliani \& Miller. The study of Kisgen (2006) found that the relationship between the leverage effect and costs of capital was higher when market value measures were used as opposed to book value measures. However, the relationship between leverage effect and costs of equity was much stronger compared to the costs of debt. Khadka (2006) conducted a study on the impact of the debt ratio indicator on the costs of capital through a sample of 15 companies from 1999 to 2005. The author then used simple regression and found that the impact between these two indicators was negligible. Thus, based on the findings of this study, we could argue that the equity ratio indicator does not affect the costs of capital of enterprises, which supports the already mentioned Modigliani \& Miller theory. The results of the study of Strebulaev (2007) showed that the use of debt in the capital structure affects the overall sources of asset coverage and thus the cost of capital is a function of the leverage indicator.

The research of Baker \& Wurgler (2015) confirms that reducing leverage reduces the risk and cost of equity but does not change the weighted average cost of capital. The mutual relation of risks and costs of capital is also portrayed in the study of Villadsen et al. (2017). Zhou et al. (2016) focused their research on the sensitivity of the cost of equity to leverage deviation and their results confirm theoretical predictions that the cost of equity is positively related to leverage deviation. Nicodemus (2017) revealed that the relationship between capital structure and total costs of capital is determined by an increase when the debt ratio increases in the capital structure (considering specific industry sectors). A sample of 41 enterprises was selected for the study and a simple correlation was used to measure the relationship between the two variables. Therefore, the author concluded that there is a direct relationship between asset ratio, total equity to debt ratio, total long-term debt to total asset ratio and total shortterm debt to total asset ratio and cost of capital. These findings imply that an increase in any of the ratios led to an increase in the cost of capital, which is in contrast to the theory of Modigliani \& Miller. The results of the research of Nenu et al. (2018) show that leverage is positively correlated with the size of the company and the share price volatility, however, the debt structure has a different impact on corporate performance.

The latest researches reverse the research direction and seek some other, non-traditional factor which may influence the capital structure and its impact on the costs of capital. Moreover, Franek \& Kashi (2018) conclude that even new hybrid methods may be used to evaluate corporate performance. The study of Bae et al. (2019) showed that high leverage is associated with substantial losses in market share due to unfavourable actions by customers and competitors; financial performance is investigated in the study of Pakurar et al. (2019) 
and Sadaf et al. (2018). Moreover, they revealed the effect of corporate social responsibility on the leverage level, which verifies the results of $\mathrm{Xu}$ et al. (2015). The importance of the ownership structure, capital structure and cost of capital is analysed in the studies of Rajverma et al. (2019) and Ramalho et al. (2018), whereas the effect of national culture on the corporate performance is depicted in the research of Andrijauskiene \& Dumciuviene (2018). These capital structure studies were conducted at both local and international levels and depict different results. Thus, they represent a gap for further exploration of the structure of capital in company financial decision-making.

\section{Data and methodology}

To quantify the effect of the capital structure on the cost of capital of Slovak enterprises, we used a dataset of 17 stock companies (no commercial bank included in the dataset due to different capital structure) issuing their stock on the Bratislava Stock Exchange. The reason for the selection of the enterprises is the need for publicly available information, which was fulfilled by these companies having their financial reports and development of stock prices. Table 1 portrays the list of selected enterprises and their core business activity according to the Nomenclature of Economic Activities in the European Community (NACE classification).

Considering the financial statements and public information on enterprises, the analysis is focused on three important corporate measures - costs of capital, capital structure and company size. As the research tries to find out whether the capital structure and company size affect the cost of capital, they are considered independent variables. On the other hand, it is monitored whether the variable cost of capital depends on the volume of other variables (dependent variable).

Table 1 | List of selected enterprises

\begin{tabular}{|l|c|}
\hline \multicolumn{1}{|c|}{ Enterprise } & NACE \\
\hline CTY GROUP, a.s. & Real estate activities \\
\hline Best Hotel Properties a.s. & Manufacture of basic pharmaceutical products \\
\hline Biotika a.s. & Management consultancy activities \\
\hline Druhá strategická, a.s. & Construction of residential and non-residential buildings \\
\hline EKOSTAV a.s. & Other engineering activities \\
\hline GEOCOMPLEX, a.s. & Renting and operating of own real estate \\
\hline CHEMINVEST, a.s. & Manufacture of paints, varnishes \\
\hline Chemolak a.s. & Other processing and preserving of fruit and vegetables \\
\hline MRAZIARNE a.s. Sladkovičovo & Manufacture of prepared feeds for farm animals \\
\hline Polnonákup ŠARIŠ, a.s. & Sawmilling of wood \\
\hline PRO POPULO PP, a.s. & Management consultancy activities \\
\hline Prvá strategická, a.s. & \\
\hline
\end{tabular}




\begin{tabular}{|l|c|}
\hline SLOVFOOD, a.s. & Renting and operating of own real estate \\
\hline Slovnaft, a.s. & Manufacture of refined petroleum products \\
\hline Zlieváreň SEZ Krompachy a.s. & Casting of iron \\
\hline ZTS Sabinov, a.s. & Manufacture of bearings \\
\hline ZTS VVÚ KOŠICE a.s. & Other research on natural sciences \\
\hline
\end{tabular}

Source: authors

The corporate capital structure is calculated as the ratio of total debt to total equity. If the resulting value is more than 1 it means that the company uses more debt than equity for financing. The coefficient of capital structure was calculated from the financial and accounting statements of the enterprises (2013-2017) using the Financial Information System on Slovak Companies. Company size is determined by the value of the total assets of enterprises. The dependent variable, cost of capital, is defined as the weighted average cost of capital (WACC). WACC is calculated using the equation (Eq. 1):

$$
W A C C=\left(\frac{E}{V} \cdot R_{e}\right)+\left(\frac{D}{V} \cdot R_{d} \cdot(1-t)\right),
$$

where $E$ is the market value of the corporate equity, $D$ is the market value of the corporate debt, $V$ is the sum of equity and debt $(V=E+D), R_{e}$ is the cost of equity, $R_{d}$ cost of debt and $t$ is the corporate tax rate.

The cost of equity is determined using the CAMP model expressed by the equation (Eq. 2):

$$
R_{e}=R_{f}+\beta \cdot M R P,
$$

where $R_{f}$ is the risk-free interest rate, $\beta$ is the systematic risk of the market and MRP is the market risk premium. The risk-free rate was determined as the average yield of government bonds of the Slovak Republic. Currently, the Slovak Republic has 17 active government bonds with an average annual yield of $3.028 \%$. The value of the $\beta$ coefficient was derived from the publication of Damodaran (2019a), using the value $\beta=1.06$, which is specific for enterprises operating in the European markets regardless of the sector. Regarding the market risk premium, we also used the research of Damodaran (2019b). In particular, the reason for drawing the information from his research was the fact that calculating market revenues $\left(R_{m}\right)$ using CAPM model (considering the difference between $R_{m}$ and $\left.R_{f}\right)$, which may be used to determine the market risk premium individually for each business and each reporting year, in some cases yielded negative market returns. This could be explained by the fact that in some cases the market revenues were higher than the risk-free interest rate. It is an anomaly, which may occur on the short-term horizon. The market risk premium was calculated using the equation (Eq. 3):

$$
M R P=M R P(U S A)+\text { risk premiumof Slovak market },
$$


where $M R P(U S A)$ is a risk premium of the American market with a value of $5.96 \%$. The risk of the Slovak market has to be regarded $(1.18 \%)$, thus the resulting value of the market risk premium is $7.14 \%$. Therefore, in the given time horizon we use the same values of the costs of equity for all selected companies.

The cost of debt is calculated as the ratio of interest costs and total debt. The obtained values of costs of equity and costs of debt are used to calculate the weighted average costs of capital (using Eq. 1), which are portrayed in Table 2. In general, it can be argued that based on the costs of capital achieved by our selected companies, their values range from $0.714 \%$ to $10.596 \%$. A high percentage of the weighted average cost of capital is typically a signal of higher risk associated with a firm's operations. Investors tend to require an additional return to neutralize this additional risk.

Table 2 | WACC of selected Slovak companies

\begin{tabular}{|c|c|c|c|c|c|}
\hline \multirow{2}{*}{ Enterprise } & \multicolumn{5}{|c|}{ WACC (\%) } \\
\hline & 2013 & 2014 & 2015 & 2016 & 2017 \\
\hline CTY GROUP, a.s. & 7.670 & 7.235 & 6.497 & 7.631 & 7.670 \\
\hline Best Hotel Properties a.s. & 9.468 & 9.829 & 0.714 & 7.094 & 6.788 \\
\hline Biotika a.s. & 8.297 & 8.268 & 7.432 & 7.588 & 8.365 \\
\hline Druhá strategická, a.s. & 6.921 & 6.244 & 6.192 & 5.272 & 5.384 \\
\hline EKOSTAV a.s. & 6.627 & 4.025 & 2.440 & 3.376 & 5.574 \\
\hline GEOCOMPLEX, a.s. & 7.283 & 7.180 & 7.497 & 10.418 & 10.447 \\
\hline CHEMINVEST, a.s. & 8.987 & 9.276 & 9.092 & 7.771 & 8.874 \\
\hline Chemolak a.s. & 6.643 & 6.760 & 6.787 & 6.569 & 6.324 \\
\hline MRAZIARNE a.s. Sladkovičovo & 5.251 & 4.448 & 5.022 & 4.931 & 4.159 \\
\hline Pol'nonákup ŠARIŠ, a.s. & 7.790 & 7.573 & 7.468 & 8.337 & 7.354 \\
\hline PRO POPULO PP, a.s. & 9.362 & 9.224 & 9.299 & 9.012 & 8.711 \\
\hline Prvá strategická, a.s. & 10.587 & 10.587 & 10.568 & 10.584 & 10.586 \\
\hline SLOVFOOD, a.s. & 9.806 & 9.906 & 10.593 & 10.596 & 10.596 \\
\hline Slovnaft, a.s. & 6.418 & 6.615 & 7.026 & 7.278 & 7.231 \\
\hline Zlieváreň SEZ Krompachy a.s. & 5.137 & 4.965 & 5.156 & 4.495 & 4.747 \\
\hline ZTS Sabinov, a.s. & 5.843 & 6.332 & 6.822 & 6.620 & 6.933 \\
\hline ZTS VVÚ KOŠICE a.s. & 6.127 & 3.392 & 4.790 & 5.121 & 4.540 \\
\hline
\end{tabular}

Source: authors 
Calculation of the presented input data is necessary to be able to examine the dependence of the capital structure and the costs of capital using descriptive statistics, correlation and regression analyses, and a statistical test to compare means of two independent samples. The quantification of the effect of the capital structure on the cost of capital is realized in the following methodological steps:

1. Testing of the normality of the dataset to determine whether or not to use parametric or non-parametric tests to compare means in two groups of enterprises - enterprises preferring equity in their financial activities and the group of enterprises where the debt exceeds the equity.

2. Correlation analysis determines the strength of linear dependence between the variables. The relation between the variables is described by the Pearson correlation coefficient. The results of this test indicate that if the $p$-value of the test is less than the determined significance level (in the study the significance level of $5 \%$ is used), the null hypothesis about the insignificance of the correlation is rejected. Thus, we claim that there is a statistically significant correlation between the variables.

3. Regression analysis clarifies the relation among selected variables and models their dependence based on a linear function. The results of the linear regression reveal the statistical significance of the model itself and the variables entering the model. The decision on the statistical significance is made based on the comparison of the $p$-values and significance level. If the $p$-value is less than the significance level, we claim that the model or its variables are statistically significant.

Based on the results, we can determine the impact of the capital structure on the cost of equity of Slovak enterprises and effects on business valuation. We compare the calculated values and discuss the relation between the variables which can influence investors' willingness and interest in the enterprise, assuming a rational way of financial decisionmaking.

\section{Results}

To confirm or reject the existence of dependency between the capital structure and the cost of capital of an enterprise, the acquired variables are analysed using the IBM SPSS software. For a better overview of the variable values, the descriptive statistics (mean, standard deviation and coefficient of variance) of them are portrayed, and the dependence between variables (capital structure, costs of capital, company size) is evaluated using the results of correlation analysis, regression analysis, and statistical test to compare means (Table 3).

Table 3 | Descriptive statistics of analysed variables

\begin{tabular}{|l|c|c|c|c|}
\hline & N & Mean & St. dev. & Coef. of var. \\
\hline Cost of capital & 85 & 0.0718 & 0.0212 & 0.2948 \\
\hline Capital structure & 85 & 1.064 & 2.6959 & 2.5345 \\
\hline Size & 85 & $29,303,929.66$ & $76,377,993.72$ & 2,6064 \\
\hline
\end{tabular}

Source: authors 
The values obtained in the descriptive statistics measures show that during the period under review the average capital structure of selected companies was approximately 1.064 . Calculating the capital structure using the ratio of debt to equity, the resulting value indicates that the enterprises have, on average, 1.064-times higher debt than equity. The average cost of capital of selected enterprises was $7.182 \%$ and represents the return rate which the capital providers demand. Considering the size of enterprises, the average value of the total assets is set at the level of $€ 29,303,929.66$.

The dependence between the variables is identified using the Pearson correlation coefficient; results are summarized in Table 4.

Table 4 | Correlation analysis of variables

\begin{tabular}{|c|c|c|c|c|}
\hline & & Cost of capital & Capital structure & Size \\
\hline \multirow{3}{*}{ Cost of capital } & Pearson correlation & 1 & $-0.555^{\star *}$ & -0.065 \\
\hline & Sig. (2-tailed) & & 0.000 & 0.557 \\
\hline & $\mathrm{N}$ & 85 & 85 & 85 \\
\hline \multirow{3}{*}{$\begin{array}{l}\text { Capital } \\
\text { structure }\end{array}$} & Pearson correlation & $-0.555^{\star *}$ & 1 & $0.529^{* *}$ \\
\hline & Sig. (2-tailed) & 0.000 & & 0.000 \\
\hline & $\mathrm{N}$ & 85 & 85 & 85 \\
\hline \multirow{3}{*}{ Size } & Pearson correlation & -0.065 & $0.529^{\star *}$ & 1 \\
\hline & Sig. (2-tailed) & 0.557 & 0.000 & \\
\hline & $\mathrm{N}$ & 85 & 85 & 85 \\
\hline
\end{tabular}

Source: authors

The correlation is significant between the variables if its $p$-value is less than the significance level of 0.05 . The results declare that there is a strong negative dependence between the costs of capital and capital structure and this correlation is statistically significant. It is then obvious that when increasing the capital structure, the costs of capital decrease, and vice versa. The correlation between the company size and the costs of capital is statistically insignificant.

In the regression analysis, it is verified whether there is a linear relationship between two or more variables. If there is any relationship between them, the strength may be determined. Thus, in the study, we assume that the capital structure affects the cost of capital in the enterprise. Based on the results of the regression analysis, the significance of model variables and of the model itself is determined at the set significance level. The quality of the model is measured by the R-squared coefficient (Table 5), which is a statistical measure that represents the proportion of the variance for a dependent variable that is explained by an independent variable or variables in a regression model. Whereas correlation explains the 
strength of the relationship between the capital structure and costs of capital, R-squared explains that $38.1 \%$ of the observed variation can be explained by the inputs of the model.

table 5 | Regression model summary

\begin{tabular}{|c|c|c|c|}
\hline Model & R Square & Adjusted R square & $\begin{array}{c}\text { Std. Error of } \\
\text { the estimate }\end{array}$ \\
\hline 1 & 0.381 & 0.266 & 0.0169 \\
\hline
\end{tabular}

Source: authors

Statistical significance of the model is portrayed in Table 6. The result shows that the regression model is statistically significant, as the p-value of the ANOVA test is less than the significance level.

Table 6 ANOVA test

\begin{tabular}{|l|c|c|c|c|c|}
\hline \multicolumn{7}{|c|}{ ANOVA } \\
\hline Model & Sum of squares & df & Mean Square & F & Sig. \\
\hline Regression & 0.014 & 2 & 0.007 & 25.229 & 0.000 \\
\hline Residual & 0.023 & 82 & 0.000 & & \\
\hline Total & 0.038 & 84 & & & \\
\hline
\end{tabular}

Source: authors

Considering the statistical significance of the model variables, the results are presented in Table 7. If the p-value of the variable is higher than the level of significance, we accept the null hypothesis, and the variable is not considered statistically significant for the regression model. Otherwise, the variable is considered statistically significant and will be a part of the resulting equation describing the dependence of the cost of capital of the enterprise on its capital structure.

Table 7 | Coefficients of regression analysis

\begin{tabular}{|l|c|c|c|c|c|}
\hline \multirow{2}{*}{ Model } & \multicolumn{7}{|c|}{$\begin{array}{c}\text { Coefficients } \\
\text { Coefficients }\end{array}$} & $\begin{array}{c}\text { Standardized } \\
\text { coefficients }\end{array}$ & \multirow{2}{*}{ t } & Sig. \\
\cline { 2 - 6 } & B & Std. Error & Beta & & \\
\hline (Constant) & 0.075 & 0.002 & & 37.570 & 0.000 \\
\hline Capital structure & -0.006 & 0.001 & -0.723 & -7.064 & 0.000 \\
\hline Size & $8.8 \mathrm{E}-011$ & 0.000 & 0.318 & 3.105 & 0.003 \\
\hline \multicolumn{7}{|l|}{ a. Dependent Variable: costs of capital } \\
\hline
\end{tabular}

Source: authors

It is evident that the p-values of the variables examined and the constant are lower than the significance level. 
Based on these facts, we can compile a regression equation (Eq. 4) indicating the dependence of capital costs on the capital structure of an enterprise:

$$
C o C=0.075-0.006 K S+8.81 E^{-011} \text { size },
$$

where $\mathrm{CoC}$ are the costs of capital, $K S$ is for the corporate capital structure and size indicates the size of the company measured by the value of total assets.

To achieve more accurate results of the study, analysis of the dependence of the cost of debt and the capital structure of the enterprise was carried out. An analysis of the dependence of the cost of equity and the corporate capital structure was not realized because the value of the costs of equity was the same for all statistical units due to the market anomaly in which $R_{m}<R_{f}$, and we were forced to use general data from the research of Damodaran (2019a). The linear dependence between the cost of debt and the capital structure is illustrated in Figure 1. The $y$-axis shows the cost of debt $\left(R_{d}\right)$, which is a dependent variable, and the $\mathrm{x}$ axis is an independent variable that is the capital structure of the enterprise $(K S)$.

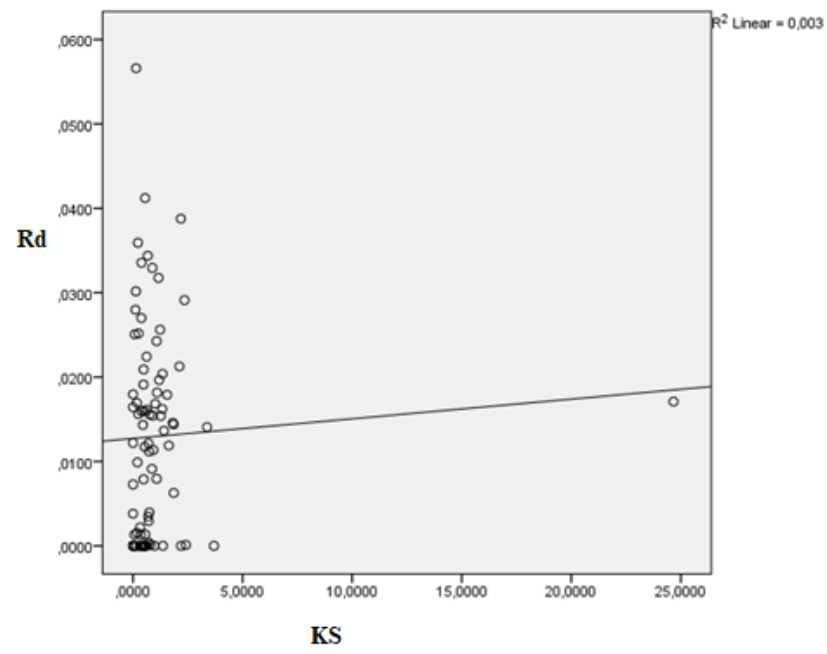

Figure 1 | Linear dependence of cost of debt and capital structure

The figure reveals that there is a dependency between variables, however, it is very weak. The line of the linear dependence is increasing, which means that dependence is directly proportional, and if the costs of debt increase, the corporate capital structure is also increasing. The value of the coefficient of determination ( $R$ Squared) is 0.003 , which means that only $0.3 \%$ of the variability of costs of debt is explained by this model. In the view of this finding, it is clear that the model explains none of the variability of the response data around its mean. Repeating the regression analysis, the results verified the low quality of the model measured by the coefficient of determination. The $p$-value of the ANOVA test was higher than the significance level $(0.64>0.05)$ indicating the regression model is not statistically significant. This result is confirmed by the testing of the statistical significance of the model variables, which shows that the only independent variable of the model is not statistically significant and cannot be considered in the regression model. 
To reveal how the capital structure influences the costs of capital, we focus on the use of the test to compare means in two groups of enterprises. The existence of differences indicates that the equity to debt ratio influences the value of the weighted average costs of capital. Before the verification, the normality of the data is tested by the Shapiro-Wilk test (Table 8). Low p- values (Sig.) indicate that the data does not follow a normal distribution and we cannot use parametric tests. The normal distribution of the dataset was not confirmed, therefore, in order to compare the means of the enterprises, the non-parametric Mann-Whitney $U$ test had to be used.

Table 8 | Test of normality

\begin{tabular}{|l|c|c|c|c|}
\hline \multirow{2}{*}{} & \multirow{2}{*}{ KS } & \multicolumn{3}{|c|}{ Shapiro-Wilk } \\
\cline { 3 - 5 } & & Statistic & Df & Sig. \\
\hline \multirow{3}{*}{ WACC } & 1 & 0.912 & 60 & 0.000 \\
\cline { 2 - 5 } & 2 & 0.917 & 25 & 0.043 \\
\hline
\end{tabular}

Source: authors

Using the non-parametric Mann-Whitney $U$ test, we can determine if there is any significant difference between the mean values of two samples of analysed enterprises. The variable capital structure is to be divided into two groups. The first group (1) consists of the enterprises whose value of the capital structure is less than 1 - the enterprises prefer the use of equity. The second group (2) is formed of enterprises using debt for financing rather than equity and the value of the capital structure is higher than 1. Based on this criterion, two groups of enterprises were determined and their descriptive statistics are presented in Table 9.

Table 9 | Descriptive statistics of capital structure

\begin{tabular}{|l|c|c|c|c|c|}
\hline \multirow{2}{*}{} & \multirow{2}{*}{ KS } & \multicolumn{4}{|c|}{ Group statistics } \\
\cline { 2 - 6 } & & $\mathbf{N}$ & Mean & St. dev. & Coef. of var. \\
\hline \multirow{3}{*}{ WACC } & 1 & 60 & 0.0819 & 0.0147 & 0.1795 \\
\cline { 2 - 6 } & 2 & 25 & 0.0477 & 0.0133 & 0.2788 \\
\hline
\end{tabular}

Source: authors

The average cost of capital between the groups is significantly different. For a group of cases where the enterprises have a greater equity-to-debt ratio, the mean value of the cost of capital was $8.189 \%$, while the mean in the second group of enterprises, preferring debt, was 4.77 $\%$. It could, therefore, be argued that if an enterprise finances its assets with a higher value of debt compared to equity, it should reduce its total costs of capital. The histogram (Figure 2) illustrates the frequencies of both groups of capital structure. In the case of group 1, the cost of capital value is higher than in the case of group 2. 


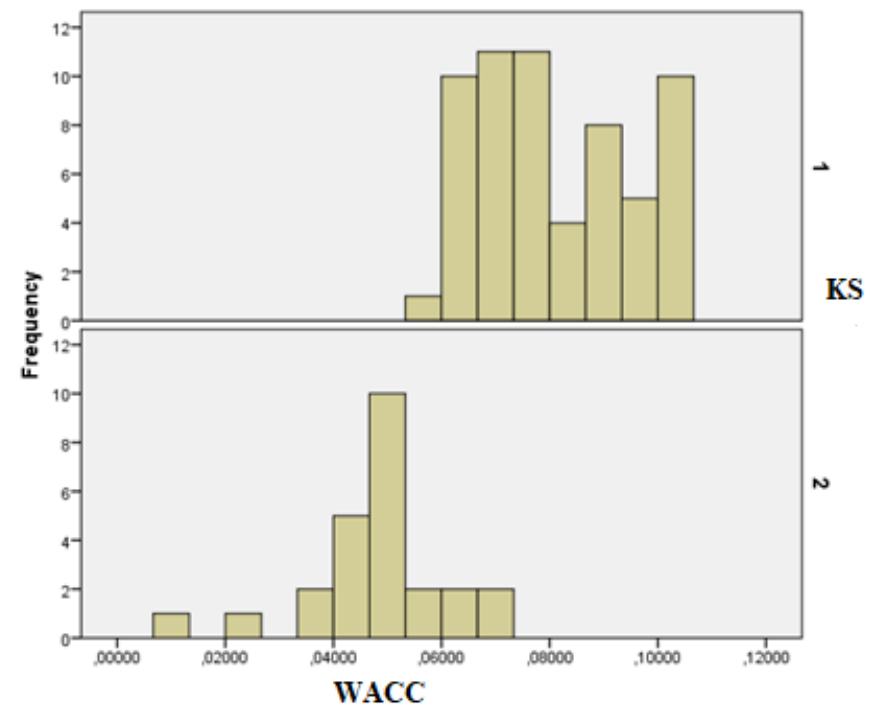

Figure 2 | Histogram of frequencies of capital structure

We verify this finding using the non-parametric Mann-Whitney U-test of independent variables. The result confirms that there are significant differences between the groups of enterprises considering their capital structure, as the p-value of Mann-Whitney tests $(0.000)$ is less than the significance level 0.05 . Nevertheless, the mean of a group of cases where the capital structure was lower than 1 has a greater variance of mean values than a group with a capital structure greater than 1 . Considering the results, it can be concluded that when financing corporate assets by more debt than equity, the weighted average costs of capital are lower compared to predominantly financing with equity.

\section{Discussion}

This study aimed to determine the impact of the capital structure on the cost of capital of selected joint stock companies operating in the Slovak market in various sectors. The originality of the study lies in the fact that this exploration was carried out under the conditions of the Slovak environment where the effect of the capital structure on costs of capital has not been sufficiently explored, yet. The background data for the case study were taken from the Bratislava Stock Exchange website and the secondary data was provided from the financial statements of the individual companies. The results of the correlation analysis reveal that the higher the value of the capital structure, the lower the costs of capital of an enterprise, as the correlation coefficient shows strong indirect dependence between the corporate capital structure and costs of equity. As the values of the capital structure were calculated as the debt-to-equity ratio, we can conclude that the values of the capital structure increase with the growth of debt. In this respect, it is obvious that with increasing amounts of debt in an enterprise, the costs of capital decrease. Regression analysis brings multifarious results. Assessing the impact of the capital structure and the size of the enterprise on the costs of capital, there is a relatively strong and direct relationship between them, which means that growth of the capital structure and the company size increases the costs of capital. On the 
other hand, these independent variables affect the dependent variable only to $38.1 \%$. However, a lot of data can be generated with a low R-squared, as demonstrated in the studies of Neter \& Wasserman (1974), Barclay (1991), Locke \& Wellalage (2014), and many others. Despite the relatively low value of the coefficient of determination, the model is statistically significant and indicates that it has significant explanatory power. In the case of the regression analysis where we assessed the impact of the capital structure on the cost of debt, we concluded that we cannot consider the regression model to be statistically significant, and thus we cannot identify the relationship between the variables (Table 10).

Table 10 Results of the regression analyses

\begin{tabular}{|c|c|c|}
\hline Variables & Resulting value & Conclusion \\
\hline \multirow{6}{*}{$\begin{array}{l}\text { Capital structure, } \\
\text { cost of capital, } \\
\text { company size }\end{array}$} & \multirow[t]{2}{*}{$\mathrm{R}^{2}=38.1 \%$} & $\begin{array}{c}\text { Capital structure and company size } \\
\text { explain } 38.1 \% \text { of the costs of } \\
\text { capital variability }\end{array}$ \\
\hline & & $\begin{array}{c}\text { The statistical significance of their } \\
\text { mutual relation was not tested. }\end{array}$ \\
\hline & p-value (Sig.) $=0.000$ & $\begin{array}{c}\text { Regression model is statistically } \\
\text { significant. }\end{array}$ \\
\hline & \multirow{3}{*}{ CoC $=0.075-0.006 K S+8.81 E^{-011}$ size } & $\begin{array}{l}\text { If the capital structure is zero, the } \\
\text { costs of capital are } 0.075 € \text { provided } \\
\text { that the capital structure and } \\
\text { company size are constant. }\end{array}$ \\
\hline & & $\begin{array}{c}\text { Increasing the capital structure of } 1 \\
\text { unit, the costs of capital decrease } \\
0.006 € \text { provided that the company } \\
\text { size is constant. }\end{array}$ \\
\hline & & $\begin{array}{l}\text { Increasing the company size of } 1 \\
\text { unit, the costs of capital increase } \\
8.81 \mathrm{E}-011 € \text { provided that the } \\
\text { capital structure is constant. }\end{array}$ \\
\hline \multirow{3}{*}{$\begin{array}{l}\text { Capital structure, } \\
\text { cost of debt }\end{array}$} & $r=0.051$ & $\begin{array}{c}\text { There is a very low dependence } \\
\text { between the capital structure and } \\
\text { costs of debt }\end{array}$ \\
\hline & $R^{2}=0.3 \%$ & $\begin{array}{l}\text { Capital structure explains only } 0.3 \\
\% \text { of the costs of debt variability. }\end{array}$ \\
\hline & $p$-value (Sig.) $=0.640$ & $\begin{array}{c}\text { Regression model is not statistically } \\
\text { significant. }\end{array}$ \\
\hline
\end{tabular}

Source: authors

Testing the mean values of the capital structure of the enterprises by the Mann-Whitney $U$ test, we proved that if an enterprise finances its assets with a greater amount of debt than equity, its total costs of capital are lower compared to an enterprise financing its assets mainly through equity.

Based on the results obtained, there is an indirect relationship between the capital structure and the cost of capital of enterprises operating in the Slovak market, which declares that with increasing values of the capital structure, the costs of capital decrease. Moreover, the analysis reveals that the growth of debt in the capital structure has impact with a decrease in the costs of capital. These findings correspond with the compromise theory of Myers \& Majluf (1984). The comparison of the results with other studies being conducted in the Slovak business environment is a bit interrogative as only two studies were realized. In 2002, Kristofik revealed in his paper devoted to the determination of capital structure that a direct 
relation between leverage and agency problems seemed to be absent. Reznakova et al. (2010) also analysed the determinants of capital structure and capital structure theories in Slovak enterprises considering the period from 2002 to 2007. Costs of capital can be used as the company's benchmark in making investment decisions to verify that the investment will bring value in generating revenue that is higher than its costs of capital (Balcerzak et al., 2019; Nipun et al., 2018). To benefit from information about the corporate costs of capital, enterprises may use data to assess their position among other companies under the interest of an investor (Kliestikova, et al., 2017; Durica et al., 2019) and also to define the key determinant influencing the corporate capital structure (Kliestik, et al. 2018; Gavurova, et al. 2017). Vochozka, et al. (2018) say that companies are able to predict the viability of future projects and should, therefore, choose the ones that will bring them the greatest value. As shown in the study results and other researchers conducted in the Slovak business environment, capital structure is an important factor in valuing business - business growth is a significant contributor not only for investors but could also be beneficial to an economy (Meyer, 2019).

\section{Conclusions}

The choice of financing makes the cost of capital a crucial variable for every enterprise as it determines its corporates capital structure. Companies look for the optimal mix of financing that provides adequate funding and that minimizes the costs of capital. Furthermore, investors use the costs of capital as one of the financial metrics they consider when evaluating companies as potential investments. Thus, many theorists and researchers have examined the relationship between the capital structure and the costs of capital and their findings declare that there exists a relation between them. The study on Slovak enterprises found that there is an indirect relationship between the capital structure, costs of capital, and the size of a company. This means that an increase in the value of the capital structure (leverage ratio) and the size of a business causes a reduction in the costs of capital at a statistically significant level. We also conclude that the growing volume of debt results in a decline in the costs of capital of the company.

Despite various calculations and analyses, there are some limitations to this research. We attempt to quantify the effect of the capital structure on the cost of capital considering the unique country samples. Thus, it would be beneficial to unveil the relation between these two measures considering more enterprises (including the ones of neighbouring countries) to verify the impact of the ownership or sector on the relation between the capital structure and the costs of capital, which would be the scope of our future research.

Financial decisions are among the most important decisions that financial managers have to face, as enterprises need to identify ways to finance their assets, operations, and growth. Given that there is a declared relationship between the corporate capital structure and costs of capital of an enterprise, it is important for enterprises not only in the Slovak market to identify the best combination of debt and equity to finance their operations, bearing in mind the costs associated with these sources of funding. It is recommended to accept the relationship between capital structure and costs of capital, otherwise the potential for additional debt to be taken without generating additional income increases. 


\section{Acknowledgement}

This contribution is an output of the scientific project VEGA 1/0210/19: Research of innovative attributes of quantitative and qualitative fundaments of the opportunistic earnings modelling.

\section{References}

Andrijauskiene, M., \& Dumciuviene, D. (2018). National culture as a determinant of firms' innovative performance. Forum Scientiae Oeconomia, 6(1), 47-67.

Bae, K. H., El Ghoul, S., Guedhami, O., Kwok, C., \& Zheng, Y. (2019). Does corporate social responsibility reduce the costs of high leverage? Evidence from capital structure and product market interactions. Journal of Banking \& Finance, 100, 135-150.

Baker, M., \& Wurgler, J. (2015). Do strict capital requirements raise the cost of capital? Bank regulation, capital structure, and the low-risk anomaly. American Economic Review, 105(5), 315-320.

Balcerzak, A. P., Kliestik, T., Streimikiene, D., \& Smrcka, L. (2018). Non-Parametric Approach to Measuring the Efficiency of Banking Sectors in European Union Countries. Acta Polytechnica Hungarica, 14(7), 51-70.

Barclay, D. L. (1991). A statistical note on trend factors: The meaning of R-squared. Casualty Actuarial Society Forum, 3, 7-18.

Barclay, M. J., \& Smith, C. W. (1995). The maturity structure of corporate debt. Journal of Finance, 50(2), 609-631.

Damodaran, A. (2019a). Total betas by sector (for computing private company costs of equity) - US. Retrieved May 12, 2019, from

http://people.stern.nyu.edu/adamodar/New_Home_Page/datafile/totalbeta.html.

Damodaran, A. (2019b). Country default spreads and risk premiums. Retrieved May 7, 2019. from http://people.stern.nyu.edu/adamodar/New_Home_Page/datafile/ctryprem.html.

Durica, M., Podhorska, I., \& Durana, P. (2019). Business failure prediction using cart-based model: A case of Slovak companies. Ekonomicko-manazerske spectrum, 13(1), 51-61.

Franek, J., \& Kashi, K. (2017). Application of hybrid MADM methods for performance evaluation in manufacturing. Forum Scientiae Oeconomia, 5(2), 41-54.

Frank, M. Z., \& Goyal, V. K. (2009). Capital structure decisions: Which factors are reliably important? Financial management, 38(1), 1-37.

Gapenski, L. C. (1987). An empirical study of the relationships between leverage and capital costs for electric utilities. Florida: Public utility research center.

Gavurová B., Misankova, M., Packova, M., \& Smrcka, L. (2017). Predictive potential and risks of selected bankruptcy prediction models in the Slovak business environment. Journal of Business Economics and Management, 18(6), 1156-1173.

Khadka, H. B. (2006). Leverage and the cost of capital: Some tests using Nepalese data. The Journal of Nepaleses Business Studies, 3(1), 85-91.

Kisgen, D. J. (2006). Credit ratings and capital structure. Journal of Finance, 41(3), 1035-1072.

Kliestik, T., Kovacova, M., Podhorska, I., \& Kliestikova, J. (2018). Searching for key sources of goodwill creation as new global managerial challenge. Polish Journal of Management Studies, 17(1), 144154. 
Kliestikova J., Misankova, M., \& Kliestik, T. (2017). Bankruptcy in Slovakia: international comparison of the creditor's position. Oeconomia Copernicana, 8(2), 221-237.

Korajczyk, R. A., \& Levy, A. (2003). Capital structure choice: macroeconomic conditions and financial constraints. Journal of Financial Economics, 68(1), 75-109.

Kristofik, P. (2002). Determinants of capital structure and financial decision-making in Slovak enterprises. Ekonomicky casopis, 50(2), 197-216.

Locke, S. M., \& Wellalage, N. H. (2014). The capital structure of Sri Lankan companies: A quantile regression analysis. Journal of Asia-Pacific Business, 15(3), 211-230.

Luigi, P., \& Sorin, V. (2009). A review of the capital structure theories. Annuals of Faculty of Economics, 3(1), 315-320.

Meyer, N. (2019). South African female entrepreneurs' business styles and their influence on various entrepreneurial factors. Forum Scientiae Oeconomia, 7(2), 25-35.

Modigliani, F., \& Miller, M. H. (1958). The cost of capital, corporation finance and the theory of investment. The American Economic Review, 48(3), 261-297.

Myers, S. C., \& Majluf, N. S. (1984). Corporate financing and investment decisions: When firms have information that investors do not have. Journal of Financial Economics, 13(2), 187-221.

Nenu, E. A., Vintila, G., \& Gherghina, S. C. (2018). The impact of capital structure on risk and firm performance: Empirical evidence for the Bucharest Stock Exchange listed companies. International Journal of Financial Studies, 6(2), 41.

Neter, J., \& Wasserman, W. (1974). Applied linear statistical models: regression, analysis of variance and experimental designs. Homewood: Irwing, Inc.

Nicodemus, K. M. (2017). Capital structure on the cost of capital of firms listed at the Nairobi securities Exchange. International Journal of Finance and Accounting, 2(1), 84-105.

Nipun, A., Kwan, P., \& Paul, D. (2018). Merger and Acquisition Pricing Using Agent Based Modelling. Economics, Management, and Financial Markets, 13(1), 84-99.

Pakurar, M., Haddad, H., Nagy, J., Popp, J., \& Olah, J. (2019). The impact of supply chain integration and internal control on financial performance in the Jordanian banking sector. Sustainability, 11(5), 1248-1268.

Rajverma, A. K., Arrawatia, R., Misra, A. K., \& Chandra, A. (2019). Ownership structure influencing the joint determination of dividend, leverage, and cost of capital. Cogent Economics \& Finance, 7(1), $1-25$.

Ramalho, J., Rita, R. M., \& Da Silva, J. V. (2018). The impact of family ownership on capital structure of firms: Exploring the role of zero-leverage, size, location and the global financial crisis. International Small Business Journal, 36(5). 574-604.

Reznakova, M., Svoboda, P., \& Polednakova, A. (2010). Determinants of capital structure: Empirical evidence from Slovakia. Ekonomicky casopis, 58(3), 237-250.

Sadaf, R., Olah, J., Popp, J., \& Mate D. (2018). An investigation of the influence of the worldwide governance and competitiveness on accounting fraud cases: A cross-country perspective. Sustainability, 10(3), 588-599.

Strebulaev, I. A. (2007). Do tests of capital structure theory mean what they say? Journal of Finance, 62(4), 1747-1787. 
Villadsen, B., Vilbert, M., Harris, D., \& Kolbe, L. (2017). Risk and return for regulated industries. London: Academic Press, Ltd - Elsevier Science, Ltd.

Vochozka, M., Kliestik, T., Kliestikova, J., \& Sion, G. (2018). Participating in a Highly Automated Society: How Artificial Intelligence Disrupts the Job Market. Economics, Management, and Financial Markets, 13(4), 57-62.

Xu, S., Liu, D., \& Huang, J. (2015). Corporate social responsibility, the cost of equity capital and ownership: An analysis of Chinese listed firms. Australian Journal of Management, 40(2), 245276.

Zhou, Q., Tan, K. J. K., Faff, R., \& Zhu, Y. S. (2016). Deviation from target capital structure, cost of equity and speed of adjustment. Journal of Corporate Finance, 39, 99-120.

The research paper has been reviewed. | Received: June 30, 2019; Revised: August 1, 2019; Accepted: August 22, 2019; Prepublished online: September 23, 2019; Published: October 1, 2019 